\title{
Anomaly and geochemistry of rare earth elements and yttrium in the late Permian coal from the Moxinpo mine, Chongqing, southwestern China
}

\author{
Jianhua Zou $\cdot$ Dong Liu $\cdot$ Heming Tian $\cdot$ Tian Li $\cdot$ Feng Liu $\cdot$ Lin Tan
}

Received: 11 February 2014/Revised: 20 March 2014/ Accepted: 20 March 2014/Published online: 12 September 2014

(C) The Author(s) 2014. This article is published with open access at Springerlink.com

\begin{abstract}
The rare earth elements and yttrium (REY) of the K2 coal from the Moxinpo mine, Chongqing, were determined using inductively coupled plasma mass spectrometry (ICP-MS). The results show that REY are enriched in the K2 coal, with the average content up to $462 \mu \mathrm{g} / \mathrm{g}$, much higher than average values of most coals in the world. The REY distribution patterns indicate that the light REY is enriched and show a well-pronounced Eu minimum. The fractionation of individual light-REY is higher than that of the heavy-REY. The REY distribution through the K2 coal seam shows that the top and bottom portion of the coal seam have a lower content of REY than the middle portion. Goyazite and rhabdophane were identified with a scanning electron microscope equipped with an energy-dispersed X-ray spectrometer (SEM-EDX). The REY distributions through the coal seam, SEM-EDX data and the correlation analysis between ash yields and the concentrations have revealed that the REY mainly occurs in the organic matter. The K2 coal is a potential rare-metal resource due to its high REY contents, and the coal ash could be regarded as a new and promising raw material for recovery of REY as a by-product.
\end{abstract}

Keywords Rare earth elements and yttrium $\cdot$ Late Permian $\cdot$ Chongqing $\cdot$ Moxinpo mine

\section{Introduction}

Owing to their unique physical and chemical properties (Chi and Tian 2006), rare earth elements and yttrium (REY), play a key role in the fields of information, biology, new energy and material, space and ocean industry. REY consumption has shown an exponential growth in recent years and will continue to grow in the foreseeable future. China has the

J. Zou $(\bowtie) \cdot$ D. Liu $\cdot$ H. Tian · T. Li · F. Liu

Chongqing Key Laboratory of Exogenic Mineralization and

Mine Environment, Chongqing Institute of Geology and Mineral

Resources, Chongqing 400042, China

e-mail: zjh1200@163.com

J. Zou · D. Liu $\cdot$ H. Tian - T. Li · F. Liu

Chongqing Research Center of State Key Laboratory of Coal

Resources and Safe Mining, Chongqing 400042, China

L. Tan

Chongqing Institute of Geological Survey, Chongqing 401122,

China most REY reserves in the world, including the light rare earth elements (LREY) in North China and heavy rare earth elements (HREY) in South China. However, the conventional REY deposits consumption has increasingly growth with the economic development of China, so discovering new REY deposit types and improving the reserves of REY become increasingly important. The REY content in coal is usually low, but REY can concentrate in coal under some specific geologic conditions. Because of their stable chemical properties during coal combustion, such as higher fusion and boiling point, the REY may primarily accumulate more in the ash (Zhao 2002; Ren et al. 2006). There are some researches on the coal deposits being potential alternative sources and a promising raw material for extracting REY as by-product in recent years (Eskenazy 1987, 1999; Seredin 1996; Ren and Dai 2009; Dai et al. 2012a, 2013, 2014; Seredin and Dai 2012).

As REY in coal-bearing have some special geochemical properties including chemical stability and little influence from metamorphism, the REY distribution, modes of 


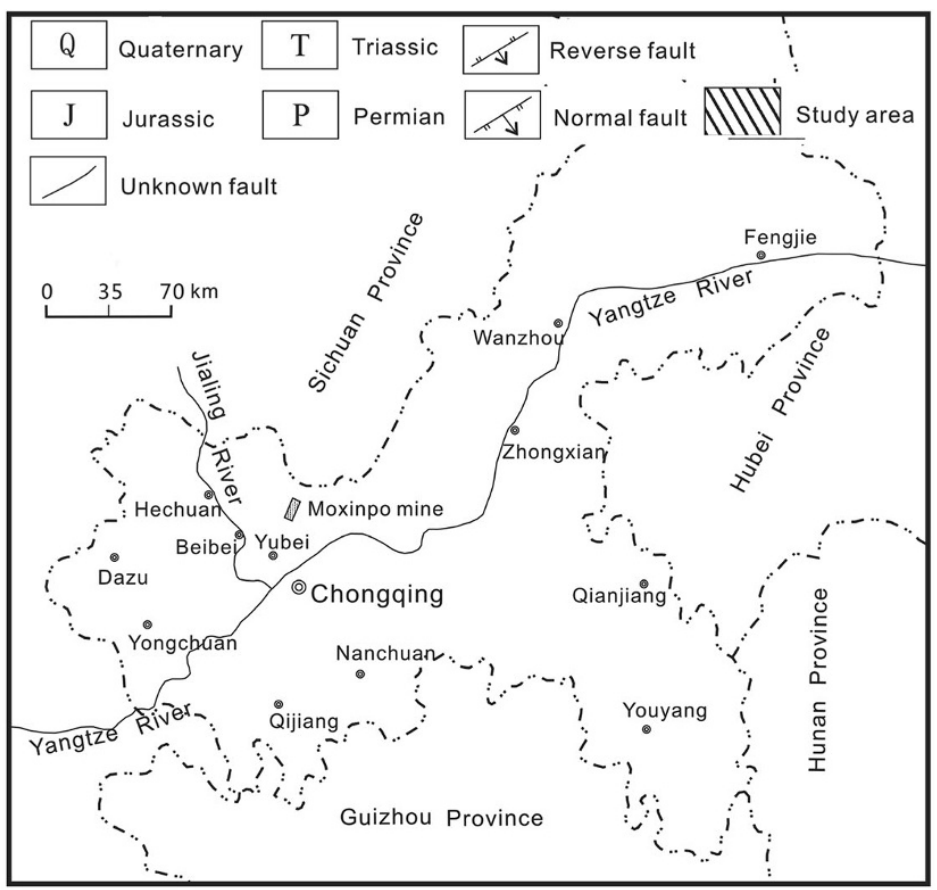

(a) Location of Moninpo mine, Chongqing

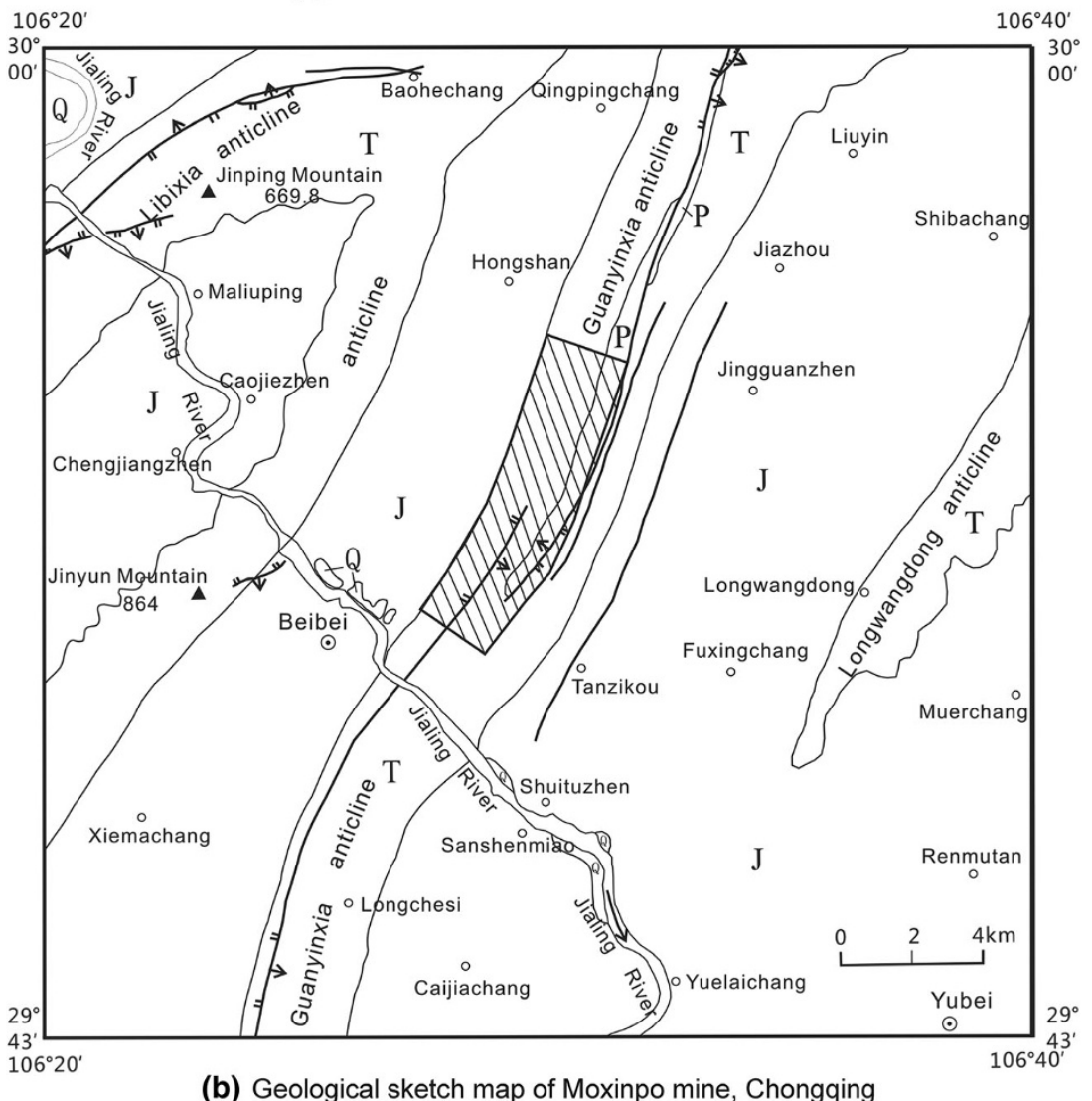

(b) Geological sketch map of Moxinpo mine, Chongqing

Fig. 1 Location and geological sketch map of the Moxinpo mine, Chongqing (Modified after Zhong et al. 2011)

occurrences and geochemical parameters are usually used as geochemical indicators and to illustrate the origin of coal accumulating materials (Zheng et al. 2006).
The K2 coal with high REY concentrations in the Moxinpo mine, which is comparable to some coal basins in the Far East, Russian (Seredin 1996), were studied. This 
paper reports the first data of the REY concentration level, distribution patterns and modes of occurrences in the $\mathrm{K} 2$ coal seam, Moxinpo mine, Tianfu Coalfield, Chongqing. It also contributes to the discussion on the prospects of their use as a new source of REY.

\section{Geological setting}

The Moxinpo mine is located in northern Chongqing, $30 \mathrm{~km}$ far away from the Chongqing urban area (Fig. 1a). The coalbearing stratum is the late Permian Longtan Formation, composed of limestone, siliceous limestone, sandstone, mudstone and coal, which is enriched in brachiopods, bivalves, dragonfly branch, cephalopods and other fossils. The Longtan Formation deposited in a confined sea carbonate tidal environment, of which the average thickness is $138.76 \mathrm{~m}$. The Longtan Formation can be divided into five portions, in which the first and third are coal-bearing portions. The major coal seam in the Moxinpo mine is the K2 coal, which is located in the first portion of the Longtan Formation. The thickness of the coal seam varies from 1.54 to $5.16 \mathrm{~m}$ and averages $3.25 \mathrm{~m}$. The Changxin Formation conformably overlies the Longtan Formation and is mainly composed of thick layers of limestone intercalated with thin layers of mudstone and rich in marine fossils. The Maokou Formation disconformably underlies the Longtan Formation, which is consisted of thick layers of limestone and enriched in marine fossil fragments, corals, flint nodules, and locally, banded mudstone.

Tectonically, the Moxinpo mine is located in southern part of Chongqing fold bundle and west limb of the Guanyinxia anticline. Tectonic line trend orients mainly NNE-SSW. Anticlines of Xishan, Libixia, Wentangxia, Guanyinxia and Longwangdong, synclines among the anticlines are the southern extension of the Chongqing fold bundle, which is a typical interval block fold and characterized by close anticlinal folds, synclinal fold-relief. The fracture zone is developed mainly by reverse fault, shown in Fig. $1 b$.

\section{Sampling and methods}

A total of 20 bench samples were taken from the working face of the mined coal in the Moxinpo mine, following the

Table 1 Concentrations of REY in the K2 coal from the Moxinpo mine, Chongqing (in $\mu \mathrm{g} / \mathrm{g}$ )

\begin{tabular}{|c|c|c|c|c|c|c|c|c|c|c|c|c|c|c|c|c|c|}
\hline Samples & Lithology & $\begin{array}{l}A_{\mathrm{d}} \\
(\%)\end{array}$ & $\mathrm{La}$ & $\mathrm{Ce}$ & $\operatorname{Pr}$ & $\mathrm{Nd}$ & $\mathrm{Sm}$ & $\mathrm{Eu}$ & $\mathrm{Gd}$ & $\mathrm{Tb}$ & Dy & $\mathrm{Y}$ & Ho & $\mathrm{Er}$ & $\mathrm{Tm}$ & $\mathrm{Yb}$ & $\mathrm{Lu}$ \\
\hline $\mathrm{K} 2-1$ & Coal & 22.02 & 23.1 & 38.3 & 4.21 & 15.5 & 3.10 & 0.50 & 3.44 & 0.56 & 2.95 & 16.0 & 0.59 & 1.39 & 0.24 & 1.27 & 0.15 \\
\hline $\mathrm{K} 2-2$ & Coal & 15.24 & 10.2 & 14.9 & 1.52 & 4.91 & 0.89 & 0.10 & 0.92 & 0.17 & 0.92 & 5.96 & 0.20 & 0.51 & 0.09 & 0.56 & 0.07 \\
\hline $\mathrm{K} 2-3$ & Coal & 13.02 & 41.5 & 50.5 & 5.36 & 18.1 & 2.85 & 0.24 & 2.77 & 0.44 & 2.27 & 11.2 & 0.45 & 1.11 & 0.19 & 1.04 & 0.12 \\
\hline $\mathrm{K} 2-4$ & Coal & 13.44 & 85.8 & 114 & 11.1 & 35.4 & 5.24 & 0.30 & 5.17 & 0.71 & 3.40 & 36.5 & 0.67 & 1.67 & 0.27 & 1.49 & 0.17 \\
\hline $\mathrm{K} 2-5$ & Coal & 19.97 & 80.1 & 110 & 10.5 & 34.8 & 5.15 & 0.32 & 5.41 & 0.90 & 4.67 & 24.3 & 0.99 & 2.54 & 0.46 & 2.60 & 0.30 \\
\hline $\mathrm{K} 2-6$ & Coal & 11.4 & 87.3 & 151 & 11.5 & 36.3 & 5.40 & 0.29 & 5.27 & 0.85 & 4.75 & 26.6 & 1.02 & 2.71 & 0.51 & 3.14 & 0.37 \\
\hline $\mathrm{K} 2-7$ & Coal & 22.06 & 134 & 334 & 30.7 & 108 & 18.57 & 0.85 & 14.9 & 2.00 & 8.29 & 66.6 & 1.59 & 4.04 & 0.69 & 4.13 & 0.49 \\
\hline K2-8 & Coal & 14.79 & 182 & 365 & 32.7 & 115 & 19.2 & 0.85 & 14.9 & 1.80 & 7.16 & 98.9 & 1.36 & 3.59 & 0.60 & 3.62 & 0.44 \\
\hline K2-9 & $\begin{array}{l}\text { Carbonaceous } \\
\text { mudstone }\end{array}$ & 53.38 & 99.3 & 212 & 25.5 & 91.3 & 15.0 & 0.66 & 11.4 & 1.63 & 7.42 & 76.5 & 1.44 & 3.58 & 0.63 & 3.78 & 0.44 \\
\hline $\mathrm{K} 2-10$ & Coal & 21.06 & 91.4 & 250 & 25.3 & 93.5 & 17.2 & 0.78 & 12.0 & 1.60 & 6.99 & 98.7 & 1.38 & 3.60 & 0.63 & 3.92 & 0.45 \\
\hline K2-11 & Coal & 13.52 & 222 & 415 & 34.3 & 111.5 & 15.3 & 0.74 & 13.2 & 1.73 & 8.19 & 29.9 & 1.68 & 4.64 & 0.89 & 5.49 & 0.65 \\
\hline $\mathrm{K} 2-12$ & Coal & 11.54 & 84.4 & 172 & 13.5 & 44.5 & 9.88 & 0.67 & 10.9 & 2.08 & 11.3 & 60.8 & 2.31 & 5.71 & 1.03 & 5.95 & 0.72 \\
\hline $\mathrm{K} 2-13$ & Coal & 12.54 & 177 & 334 & 27.8 & 90.8 & 12.9 & 0.64 & 11.3 & 1.57 & 7.51 & 46.6 & 1.55 & 4.09 & 0.74 & 4.45 & 0.54 \\
\hline K2-14 & Coal & 11.54 & 50.2 & 99.0 & 12.2 & 47.1 & 8.59 & 0.48 & 6.99 & 1.11 & 5.55 & 30.5 & 1.17 & 3.06 & 0.58 & 3.58 & 0.44 \\
\hline $\mathrm{K} 2-15$ & Coal & 16.09 & 119 & 303 & 30.7 & 117 & 21.6 & 1.12 & 16.0 & 1.91 & 6.55 & 68.6 & 1.14 & 2.85 & 0.46 & 2.91 & 0.34 \\
\hline $\mathrm{K} 2-16$ & Coal & 19.04 & 51.6 & 111 & 13.6 & 52.6 & 10.2 & 0.60 & 8.51 & 1.44 & 7.48 & 62.8 & 1.55 & 3.96 & 0.72 & 4.32 & 0.54 \\
\hline K2-17 & Coal & 23.64 & 50.4 & 98.3 & 11.4 & 41.8 & 7.49 & 0.45 & 6.60 & 1.07 & 5.51 & 61.0 & 1.18 & 3.03 & 0.54 & 3.29 & 0.41 \\
\hline K2-18 & Coal & 20.9 & 95.3 & 164.7 & 19.6 & 73.2 & 12.7 & 0.87 & 10.9 & 1.65 & 7.80 & 39.2 & 1.52 & 3.82 & 0.68 & 4.16 & 0.50 \\
\hline K2-19 & Coal & 12.36 & 183 & 358 & 33.6 & 118 & 17.6 & 0.89 & 14.8 & 2.06 & 9.76 & 130 & 2.06 & 5.59 & 1.08 & 6.74 & 0.83 \\
\hline $\mathrm{K} 2-20$ & $\begin{array}{l}\text { Carbonaceous } \\
\text { mudstone }\end{array}$ & 85.58 & 85.6 & 140 & 14.9 & 45.9 & 9.41 & 0.64 & 9.67 & 1.87 & 10.6 & 42.8 & 2.17 & 5.58 & 1.11 & 6.68 & 0.77 \\
\hline $\begin{array}{c}\text { WA in } \\
\text { coal }\end{array}$ & & 16.34 & 98.2 & 193 & 18.3 & 64.3 & 10.8 & 0.59 & 9.11 & 1.31 & 6.17 & 50.8 & 1.25 & 3.22 & 0.58 & 3.48 & 0.42 \\
\hline
\end{tabular}

A, ash yield; d, dry bais; WA, weighted average 
Chinese Standard GB/T482-2008, including 18 coal benches, one parting and one floor samples. Each coal bench sample was cut over an area $10 \mathrm{~cm}$ wide, $10 \mathrm{~cm}$ deep, and $10 \mathrm{~cm}$ thick. All collected samples were immediately stored in plastic bags to minimize contamination and oxidation.

Samples were crushed and ground to 200 meshes for coal chemical analysis. The ash yield was conducted according to the Chinese Standard GB/T212-2008. The contents of REY were determined by inductively coupled mass spectrometry (Thermo X series II ICP-MS). A scanning electron microscope (JEOL-JSM 6610LV, accelerating voltage $20 \mathrm{kV}$ ) in conjunction with an energy-dispersed $\mathrm{X}$-ray spectrometer (SEM-EDX) was used to study the characteristics of the minerals in the coal. The procedures of ICP-MS were: weighed $0.25 \mathrm{~g}$ sample in a $50 \mathrm{~mL}$ Teflon beaker, added $20 \mathrm{~mL} \mathrm{HNO}_{3}-\mathrm{HClO}_{4}$ - $\mathrm{HF}$ (volume ratio of 4:1:5) and $2 \mathrm{~mL} \mathrm{H}_{2} \mathrm{SO}_{4}$, placed in a temperature controlled heating plate and heated to $230{ }^{\circ} \mathrm{C}$ like wet salt, then heated to $280{ }^{\circ} \mathrm{C}$ and evaporated to dryness, turned off the heating plate to make the sample cooling for $3 \mathrm{~min}$, added $8 \mathrm{~mL}$ concentrated aqua regia, incubated for $10 \mathrm{~min}$, transferred the solution to a $25 \mathrm{~mL}$ plastic flask, mixed and volumed, then took $5 \mathrm{~mL}$ of solution to a $25 \mathrm{~mL}$ volumetric flask and diluted to the mark, then measured under the high resolution inductively coupled plasma mass spectrometry instrument.

\section{Results and discussion}

\subsection{REY content in coal}

The abundances and geochemical parameters of REY in the $\mathrm{K} 2$ coal benches, parting, and floor samples, are listed in Tables 1 and 2, respectively. According to the Moxinpo coal exploration geological report, the average vitrinite reflectance of the $\mathrm{K} 2$ coal is $1.55 \%$, indicating a coking coal (Chongqing Institute of Geology and Mineral Resources 2010). The content of total REY in the Moxinpo

Table 2 REY geochemical parameters in the K2 coal from the Moxinpo mine, Chongqing $(\mu \mathrm{g} / \mathrm{g})$

\begin{tabular}{|c|c|c|c|c|c|c|c|c|c|c|c|c|c|c|}
\hline Samples & $\begin{array}{l}\sum \mathrm{REY} \\
(\mathrm{Coal} \\
\text { basis })\end{array}$ & $\begin{array}{l}\text { ¿REY } \\
\text { (Ash } \\
\text { basis) }\end{array}$ & LREY & MREY & HREY & $\mathrm{L} / \mathrm{M}$ & $\mathrm{L} / \mathrm{H}$ & $\mathrm{M} / \mathrm{H}$ & $\begin{array}{l}(\mathrm{La} / \\
\mathrm{Lu})_{\mathrm{N}}\end{array}$ & $\begin{array}{l}(\mathrm{La} / \\
\mathrm{Sm})_{\mathrm{N}}\end{array}$ & $\begin{array}{l}(\mathrm{Gd} / \\
\mathrm{Lu})_{\mathrm{N}}\end{array}$ & $\begin{array}{l}\text { Enrichment } \\
\text { type }\end{array}$ & $\delta \mathrm{Ce}$ & $\delta \mathrm{Eu}$ \\
\hline K2-1 & 111 & 506 & 84.25 & 23.44 & 3.63 & 3.59 & 23.19 & 6.45 & 1.57 & 1.12 & 1.84 & $\mathrm{~L}$ & 0.89 & 0.70 \\
\hline K2-2 & 41.9 & 275 & 32.37 & 8.07 & 1.42 & 4.01 & 22.72 & 5.66 & 1.56 & 1.72 & 1.11 & $\mathrm{~L}$ & 0.86 & 0.50 \\
\hline K2-3 & 138 & 1,061 & 118.36 & 16.92 & 2.91 & 6.99 & 40.73 & 5.82 & 3.43 & 2.18 & 1.81 & $\mathrm{~L}$ & 0.77 & 0.40 \\
\hline K2-4 & 302 & 2,246 & 251.53 & 46.09 & 4.27 & 5.46 & 58.87 & 10.79 & 4.98 & 2.45 & 2.37 & $\mathrm{~L}$ & 0.84 & 0.27 \\
\hline $\mathrm{K} 2-5$ & 283 & 1,415 & 240.14 & 35.61 & 6.88 & 6.74 & 34.92 & 5.18 & 2.64 & 2.33 & 1.41 & $\mathrm{~L}$ & 0.86 & 0.28 \\
\hline K2-6 & 337 & 2,955 & 291.32 & 37.76 & 7.75 & 7.71 & 37.57 & 4.87 & 2.34 & 2.42 & 1.12 & $\mathrm{~L}$ & 1.08 & 0.25 \\
\hline K2-7 & 730 & 3,308 & 626.11 & 92.64 & 10.94 & 6.76 & 57.26 & 8.47 & 2.76 & 1.08 & 2.41 & $\mathrm{~L}$ & 1.19 & 0.24 \\
\hline K2-8 & 847 & 5,729 & 714.06 & 123.65 & 9.61 & 5.77 & 74.27 & 12.86 & 4.17 & 1.42 & 2.70 & $\mathrm{~L}$ & 1.08 & 0.23 \\
\hline K2-9 & 551 & 1,032 & 443.48 & 97.63 & 9.87 & 4.54 & 44.93 & 9.89 & 2.27 & 0.99 & 2.06 & M & 0.96 & 0.23 \\
\hline $\mathrm{K} 2-10$ & 608 & 2,886 & 477.81 & 120.03 & 9.98 & 3.98 & 47.86 & 12.02 & 2.01 & 0.80 & 2.08 & M & 1.19 & 0.25 \\
\hline K2-11 & 866 & 6,403 & 798.63 & 53.76 & 13.34 & 14.86 & 59.85 & 4.03 & 3.39 & 2.18 & 1.59 & $\mathrm{~L}$ & 1.09 & 0.24 \\
\hline $\mathrm{K} 2-12$ & 426 & 3,692 & 324.69 & 85.69 & 15.73 & 3.79 & 20.65 & 5.45 & 1.18 & 1.28 & 1.19 & $\mathrm{~L}$ & 1.16 & 0.30 \\
\hline K2-13 & 722 & 5,757 & 642.93 & 67.65 & 11.38 & 9.50 & 56.52 & 5.95 & 3.27 & 2.05 & 1.65 & $\mathrm{~L}$ & 1.09 & 0.24 \\
\hline K2-14 & 271 & 2,345 & 217.11 & 44.64 & 8.82 & 4.86 & 24.62 & 5.06 & 1.14 & 0.88 & 1.25 & M & 0.91 & 0.29 \\
\hline K2-15 & 693 & 4,307 & 591.15 & 94.13 & 7.70 & 6.28 & 76.75 & 12.22 & 3.50 & 0.83 & 3.69 & M & 1.14 & 0.28 \\
\hline K2-16 & 331 & 1,738 & 238.97 & 80.83 & 11.09 & 2.96 & 21.55 & 7.29 & 0.96 & 0.76 & 1.25 & M & 0.96 & 0.30 \\
\hline K2-17 & 293 & 1,237 & 209.47 & 74.62 & 8.44 & 2.81 & 24.82 & 8.84 & 1.24 & 1.01 & 1.28 & $\mathrm{~L}$ & 0.93 & 0.29 \\
\hline K2-18 & 437 & 2,089 & 365.46 & 60.37 & 10.68 & 6.05 & 34.21 & 5.65 & 1.90 & 1.13 & 1.71 & $\mathrm{~L}$ & 0.87 & 0.34 \\
\hline K2-19 & 885 & 7,157 & 710.82 & 157.55 & 16.29 & 4.51 & 43.64 & 9.67 & 2.21 & 1.56 & 1.42 & $\mathrm{~L}$ & 1.04 & 0.25 \\
\hline $\mathrm{K} 2-20$ & 377 & 441 & 295.25 & 65.59 & 16.30 & 4.50 & 18.11 & 4.02 & 1.11 & 1.36 & 0.99 & $\mathrm{~L}$ & 0.89 & 0.31 \\
\hline $\begin{array}{c}\text { WA in } \\
\text { coal }\end{array}$ & 462 & 3,061 & 385 & 68.0 & 8.94 & 5.92 & 42.22 & 7.57 & 2.46 & 1.51 & 1.77 & & 1.00 & 0.31 \\
\hline
\end{tabular}

$\Sigma$ REY is the sum of La, Ce, Pr, Nd, Sm, Eu, Gd, Tb, Dy, Y, Ho, Er, Tm, Yb and Lu; LREY means the sum of La, Ce, Pr, Nd and Sm; MREY means the sum of Eu, Gd, Tb, Dy and Y; HREY means the sum of Ho, Er, Tm, Yb and Lu; L/M is the ratio of LREY and MREY; L/H is the ratio of LREY and HREY; M/H is the ratio of MREY and HREY; $(\mathrm{La} / \mathrm{Lu})_{\mathrm{N}}$ is the ratio of $(\mathrm{La})_{\mathrm{N}}$ and $(\mathrm{Lu})_{\mathrm{N}} ;(\mathrm{La} / \mathrm{Sm})_{\mathrm{N}}$, ratio of $(\mathrm{La})_{\mathrm{N}}$ and $(\mathrm{Sm})_{\mathrm{N}} ;(\mathrm{Gd} /$ $\mathrm{Lu})_{\mathrm{N}}$, ratio of $(\mathrm{Gd})_{\mathrm{N}}$ and $(\mathrm{Lu})_{\mathrm{N}} ; \delta \mathrm{Ce}=\mathrm{Ce}_{\mathrm{N}} /\left(\mathrm{La}_{\mathrm{N}} \times \operatorname{Pr}_{\mathrm{N}}\right)^{1 / 2} ; \delta \mathrm{Eu}=\mathrm{Eu}_{\mathrm{N}} /\left(\mathrm{Sm}_{\mathrm{N}} \times \mathrm{Gd}_{\mathrm{N}}\right)^{1 / 2} ; \mathrm{N}$, REY are normalized by Upper Continental Crust (UCC) (Taylor and McLennan 1985). L, light REY enrichment; M, medium REY enrichment 


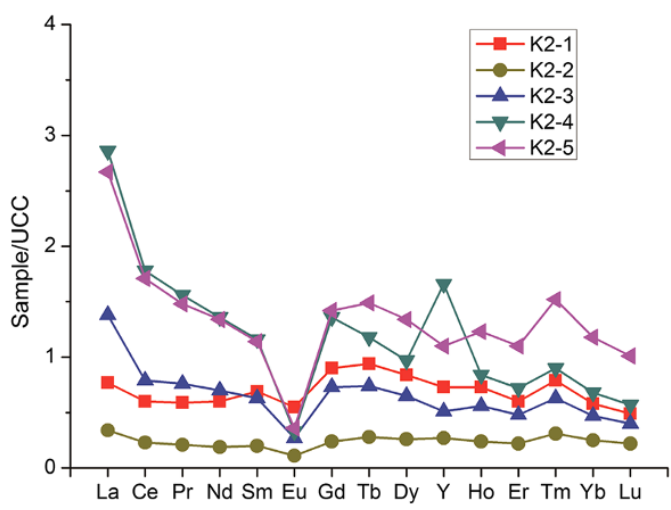

(a) Plots of LREY enrichment type

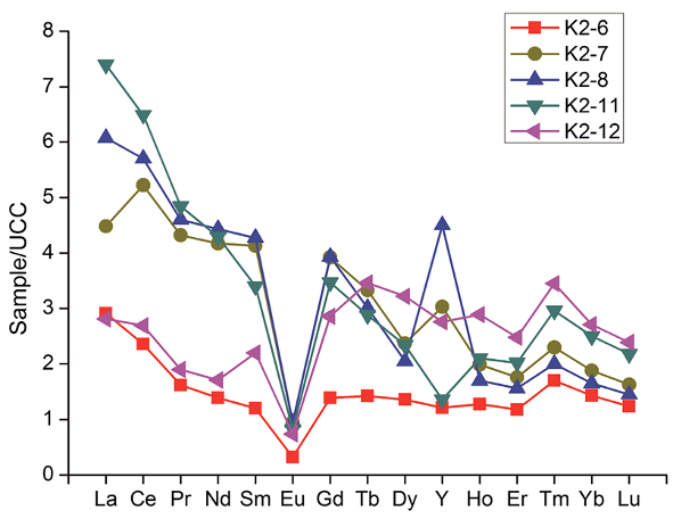

(b) Plots of LREY enrichment type

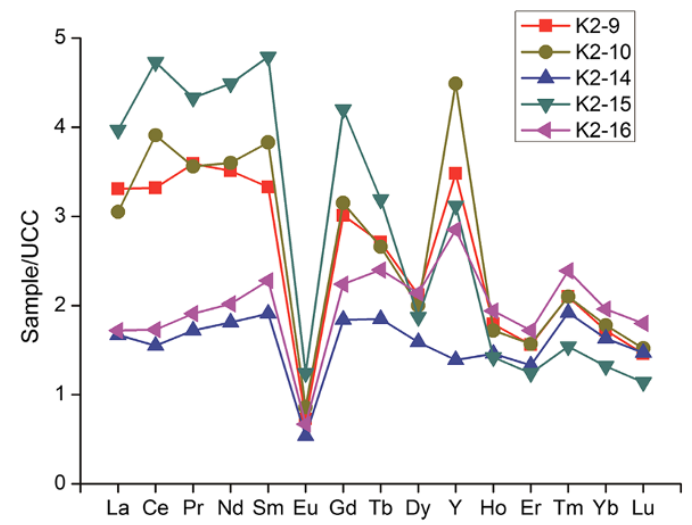

(c) Plots of MREY enrichment type

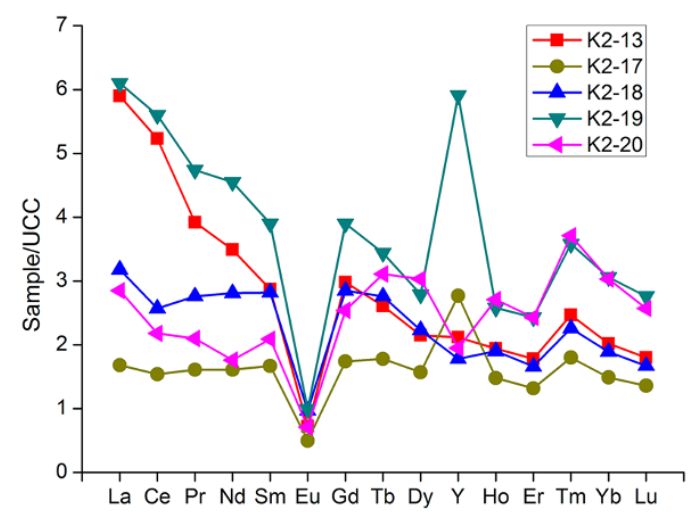

(d) Plots of LREY enrichment type
४Fig. 2 REY distribution patterns in the $\mathrm{K} 2$ samples of the Moxinpo mine, Chongqing

coals varies from 41.4 to $885 \mu \mathrm{g} / \mathrm{g}$, with an average of $462 \mu \mathrm{g} / \mathrm{g}$, higher than the average value in common Chinese coals (136 $\mu \mathrm{g} / \mathrm{g}$; Dai et al. 2012b) and common world coals $(68.5 \mu \mathrm{g} / \mathrm{g}$; Ketris and Yudovich 2009). The content of total REY in the Moxinpo coal ashes varies from 214 to $7157 \mu \mathrm{g} / \mathrm{g}$, averages $3061 \mu \mathrm{g} / \mathrm{g}$, much higher than Chinese upper crust $(87.2 \mu \mathrm{g} / \mathrm{g}$; Li 1994) and the upper continental crust $(168 \mu \mathrm{g} / \mathrm{g}$; Taylor and McLennan 1985).

\subsection{REY geochemistry}

Yttrium is closely associated with lanthanides in nature, because its ionic radius is very similar and its ionic charge is equal to that of Ho (Seredin and Dai 2012). For this reason, yttrium is generally placed between Dy and Ho in normalized REY plots (Bao and Zhao 2008). A three-fold geochemical classification of REY was used in the present study, including light (L-REY: La, Ce, Pr, Nd, and Sm), medium (M-REY: Eu, Gd, Tb, Dy, and Y), and heavy (HREY: Ho, Er, Tm, Yb, and Lu) REY (Seredin and Dai 2012). Accordingly, three enrichment types are identified, L-type (light REY; $\mathrm{La}_{\mathrm{N}} / \mathrm{Lu}_{\mathrm{N}}>1$ ), M-type (medium REY; $\mathrm{La}_{\mathrm{N}} / \mathrm{Sm}_{\mathrm{N}}<1, \mathrm{Gd}_{\mathrm{N}} / \mathrm{Lu}_{\mathrm{N}}>1$ ), and H-type (heavy REY; $\mathrm{La}_{\mathrm{N}} /$ $\mathrm{Lu}_{\mathrm{N}}<1$ ), in comparison with the upper continental crust (UCC) (Seredin and Dai 2012). Table 2 and Fig. 2 illustrate that the $\mathrm{K} 2$ coal in the Moxinpo mine are mainly enriched in light REY, only the samples of K2-9, K2-10, $\mathrm{K} 2-15$ and K2-16 are enriched in medium REY. From top to bottom, the REY enrichment type of the K2 coal can be divided into five sections, in which Sect. 1 (from K2-1 to K2-8), Sect. 2 (from K2-11 to K2-13) and Sect. 3 (from K2-17 to K2-20) are L-type enrichment, Sect. 4 (from K2-9 to K2-10) and Sect. 5 (from K2-14 to K2-16) are M-type enrichment. The L-type coals of the Moxinpo mine appear a broad V-shape curve (Fig. 2), the La-Sm portion and GdLu portion curves are steep and smooth, respectively, demonstrating that the fractionation of light REY is high, and that of the heavy REY is low. The $\delta \mathrm{Ce}$ values vary from 0.77 to 1.14 , with an average of 0.99 , indicating a slight Ce positive anomaly. The $\delta \mathrm{Eu}$ varying from 0.23 to 0.77 , with an average of 0.31 , shows a well-pronounced $\mathrm{Eu}$ minimum.

\subsection{REY distribution through the $\mathrm{K} 2$ coal seam}

The REY content variations through the $\mathrm{K} 2$ coal in the Moxinpo mine shows that the top and bottom portion of the coal seam have relatively lower contents than the middle portion (Fig. 3), indicating a certain REY fractionation. In addition, samples K2-9 and K2-20, the lithology of which 


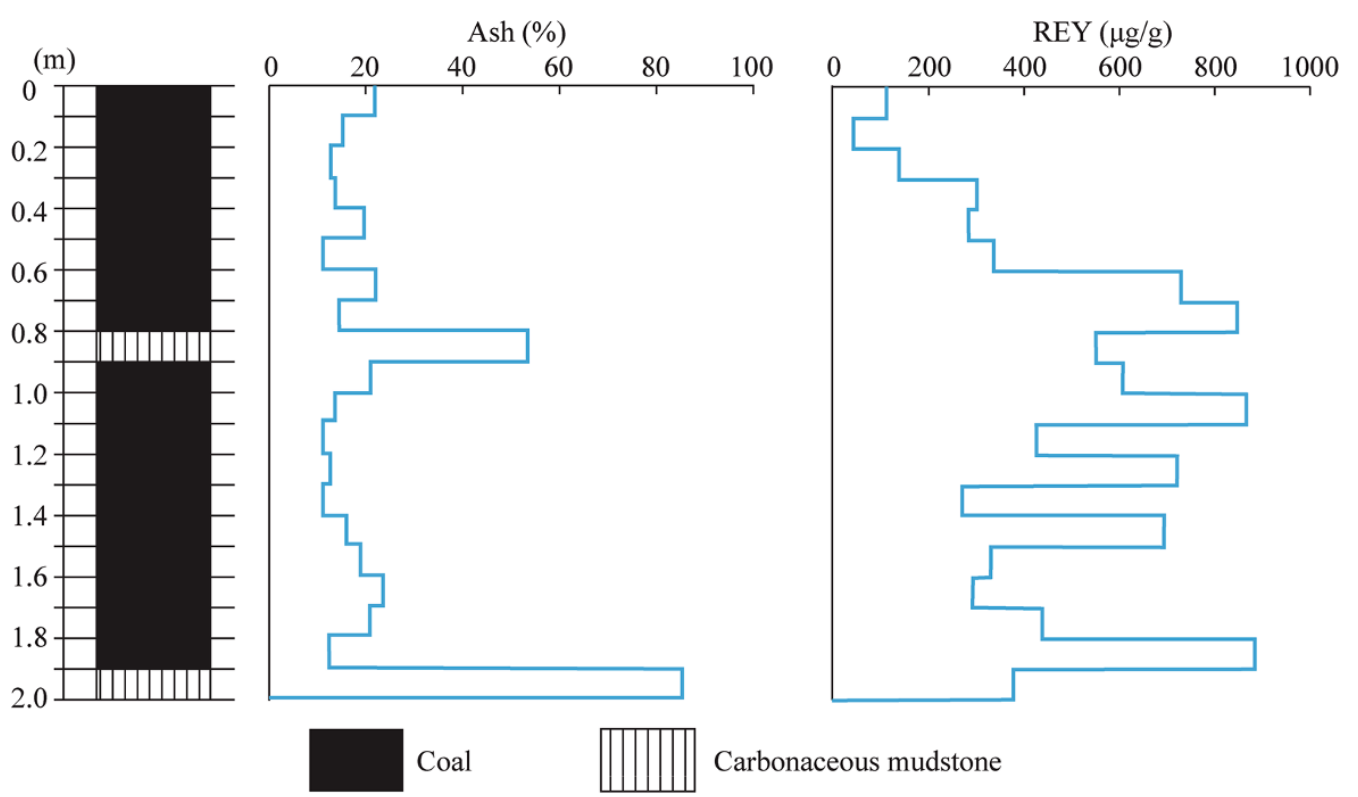

Fig. 3 Ash and REY variations through the K2 coal seam of the Moxinpo mine, Chongqing

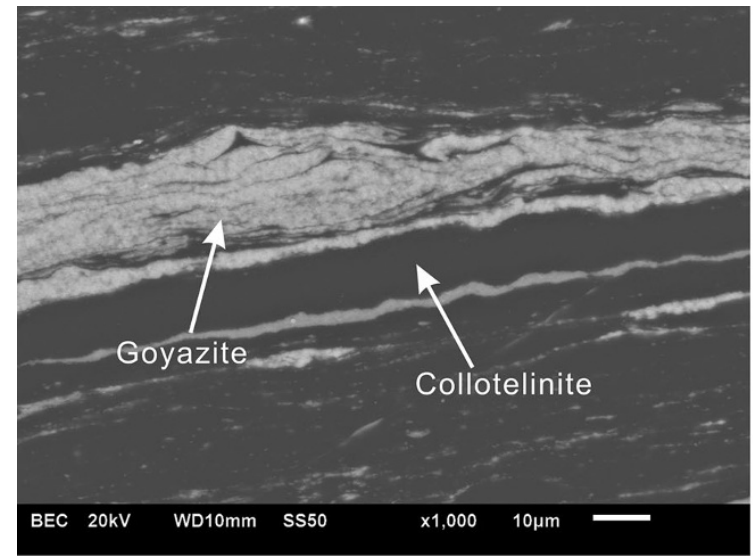

(a) Goyazite

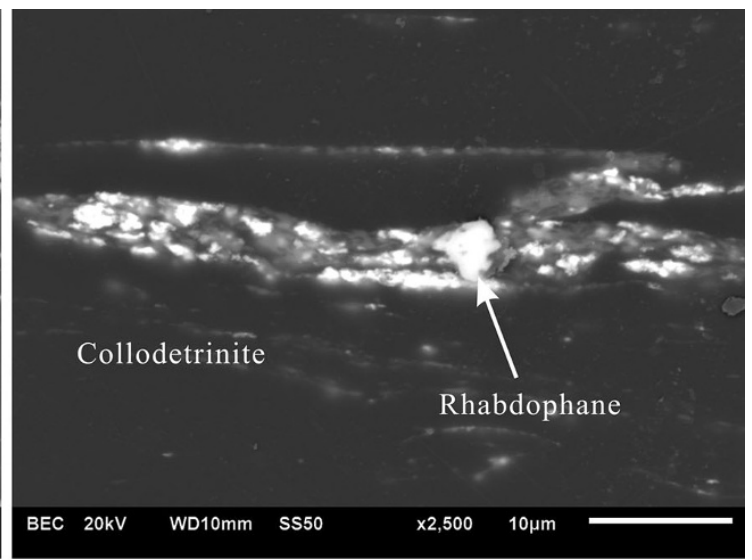

(b) Rhabdophane

Fig. 4 Goyazite and rhabdophane in the K2 coal from the Moxinpo mine, Chongqing (SEM)

is carbonaceous mudstone, are parting and floor of the $\mathrm{K} 2$ coal, respectively. The REY contents of samples K2-9 and K2-20 are comparable to those of coal samples of K2 reflect that lithology differences have a weak impact on REY content through the K2 coal seam, similar to the REY distribution of the Pavlovsk coals in Russian Far East (Seredin 1996).

\subsection{Discovery of REY-bearing mineral in the $\mathrm{K} 2$ coal}

Finely-dispersed REY-bearing minerals of the $\mathrm{K} 2$ coal in the Moxinpo mine, including goyazite (Fig. 4a) and rhabdophane (Fig. 4b) were identified using SEM-EDX.
Goyazite is a relatively common mineral in coal (Ward 2002). Aluminum phosphate containing high Sr content was recognized as goyazite under SEM. The goyazite in the K2 coal of the Moxinpo mine distributes along the bedding planes, suggesting a syngenetical origin. Dai et al. (2005) found goyazite occurring as fillings along with boehmite in fusinite cavities in the No. 6 coal seam in the Junger Coalfield. Dai et al. (2013) also found goyazite in the partings of the late Permian coals in the Fusui Coalfield, which was thought to be formed by the reaction between $\mathrm{P}$ released from organic matter in peat swamp and Al-rich solution and $\mathrm{Sr}$ leached from limestone. Rhabdophane is a light REY-bearing mineral, the $\mathrm{Ce}$ of which can 
be replaced by La, Nd, Y and Th (Wang et al. 1987). Rhabdophane in the K2 coal of the Moxinpo mine occured in the collodetrinite unevenly, indicating an authigenic origin. Dai et al. (2013) found rhabdophane in the partings of late Permian coal from the Fusui Coalfield. However, the medium- and heavy-REY minerals were not identified in the coals present in this study.

\subsection{Occurrences of REY and its relationship with ash}

No correlation (correlation coefficient of -0.06 ; Fig. 3) was found between the REY content and the ash yield of the $\mathrm{K} 2$ coal in the Moxinpo mine. With increasing REY atomic number, the correlation coefficient between REY and ash becomes gradually high (Fig. 5). However, overall, REY contents and ash yield are irrelevant or weakly correlated, indicating that the mode of occurrence of REY may be not only associated with minerals, but also with organic matter in the coal. Generally, REY in coal mainly originated from terrigenous material, in conjunction with the aluminosilicate minerals, which are generally major components of coal ash (Zhao 2002). Some studies have shown that the REY abundance increases with the increasing ash yield of the coals (Wang et al. 1989; Zou et al. 2013). However, the average content of REY in the Moxinpo coal and coal ash is up to $462 \mu \mathrm{g} / \mathrm{g}$ and $3061 \mu \mathrm{g} /$ $\mathrm{g}$, respectively, much higher than the general mudstone REY content (typically 200-300 $\mu \mathrm{g} / \mathrm{g}$; Zhao 2002), indicating that elevated contents of REY in the $\mathrm{K} 2$ coal of the Moxinpo is not provided by terrigenous materials alone, but organic matter plays an important role in the accumulation of REY in the coal. In addition, the content of REY of K2-19 higher than K2-20 (floor sample) and no correlation between REY and ash indicated that REY of the $\mathrm{K} 2$ coal in the Moxinpo mine is mainly associated with organic matter, other than minerals, which are similar to

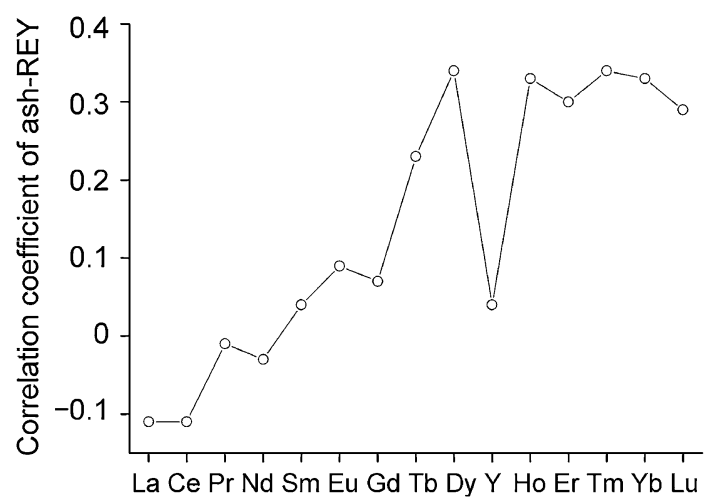

Fig. 5 Relationship between REY-ash correlation coefficients and REY atomic number the results studied by Seredin (1996). Eskenazy (1987) found that organic compounds accounted for a large proportion of REY in the low-ash coal in Bulgaria and enriched more HREY, which may be a result of the interaction between the dissolved REY and the products of disintegration and decay of organic substances, mainly the humic acids. Seredin (1996) found that organic matter played a dominant role to the REY of coal in the Russian Far East, while fine-grained authigenic minerals and forms sorbed by the clay particles are of subordinate significance.

\subsection{Preliminary evaluation of coal ash as a potential REY deposit}

The average content of REY in coal ash in the Moxinpo mine is up to $3061 \mu \mathrm{g} / \mathrm{g}$, much higher than the cut-off grade of REY in coal ash (REO-0.1\%) proposed by Seredin and Dai (Seredin and Dai 2012). The K2 coal distribution in the Moxinpo is stable and the average thickness of the $\mathrm{K} 2$ coal is about $2 \mathrm{~m}$; thus it can be used as a potential REY resource and deserves further study of the extraction technology of REY from coal ash.

\section{Conclusions}

(1) The average contents of REY in the K2 coal and ash of the Moxinpo mine are up to $462 \mu \mathrm{g} / \mathrm{g}$ and $3061 \mu \mathrm{g} / \mathrm{g}$, respectively, higher than the cut-off grade of REY in coal ash (REO-0.1\%) proposed by Seredin and Dai (Seredin and Dai 2012), indicating a potential REY deposits.

(2) The L-REY is the main REY type of the K2 coal in the Moxinpo mine, followed by the MREY. The REY distribution through the K2 coal shows that the top and bottom portion of the coal seam has a lower content of REY than that in the middle portion.

(3) The occurrence of REY in the K2 coal of the Moxinpo mine may be associated mainly with organic matter and a small proportion occurs in minerals.

(4) The K2 coal in the Moxinpo mine can be considered as a potential resource of REY and coal ash is a promising raw material for extracting REY as a by-product.

Acknowledgments This research was supported by the National Key Basic Research and Development Program (No.2014CB238902) and National Natural Science Foundation of China (No. 41302128).

Open Access This article is distributed under the terms of the Creative Commons Attribution License which permits any use, distribution, and reproduction in any medium, provided the original author(s) and the source are credited. 


\section{References}

Bao ZW, Zhao ZH (2008) Geochemistry of mineralization with exchangeable REY in the weathering crusts of granitic rocks in South China. Ore Geol Rev 33:519-535

Chi RA, Tian J (2006) Chemical metallurgy of weathered elutiondeposited rare earth ore. Science Press, Beijing, pp 1-287 (in Chinese)

Chinese Standard GB/T212-2008 (2008) Proximate analysis of coal (in Chinese)

Chinese Standard GB/T482-2008 (2008) Collective methods of coal bench sample (in Chinese)

Chongqing Institute of Geology and Mineral Resources (2010) The Moxinpo succeeding coal resources exploration geological report (in Chinese)

Dai SF, Ren DY, Chou CL, Li SS (2005) Mineralogy and geochemistry of the No. 6 coal (Pennsylvanian) in the Junger Coalfield, Ordos Basin. China. International Journal of Coal Geology 66:253-270

Dai SF, Jiang YF, Ward CR, Gu LD, Seredin VV, Liu HD, Zhou D, Wang XB, Sun YZ, Zou JH, Ren DY (2012a) Mineralogical and geochemical compositions of the coal in the Guanbanwusu mine, Inner Mongolia, China: further evidence of an $\mathrm{Al}$ (Ga and REE) ore deposit in the Jungar coalfield. Int J Coal Geol 98:10-40

Dai SF, Ren DY, Chou CL, Finkelman RB, Seredin VV, Zhou YP (2012b) Geochemistry of trace elemets in Chinese coals: a review of abundances, genetic types, impacts on human health, and industrial utilization. Int J Coal Geol 94:3-21

Dai SF, Zhang WG, Ward CR, Seredin V, Hower JC, Li X, Song WJ, Wang XB, Kang H, Zheng LC, Wang PP, Zhou D (2013) Mineralogical and geochemical anomalies of late Permian coals from the Fusui Coalfield, Guangxi Province, Southern China: influences of terrigenous materials and hydrothermal fluids. Int J Coal Geol 105:60-84

Dai SF, Luo YB, Seredin VV, Ward CR, Hower JC, Zhao L, Liu SD, Tian HM, Zou JH (2014) Revisiting the late Permian coal from the Huayinshang, Sichuan, southwestern China: enrichment and occurrence modes of minerals and trace elements. Int $\mathrm{J}$ Coal Geol 122:110-128

Eskenazy GM (1987) Rare earth elements in a sampled coal from the Pirin Deposit, Bulgaria. Int J Coal Geol 7:301-314

Eskenazy GM (1999) Aspects of the geochemistry of rare earth elements in coal: an experimental approach. Int J Coal Geol 38:285-295
Ketris MP, Yudovich YE (2009) Estimations of clarkes for carbonaceous biolithes: world average for trace element contents in black shales and coals. Int J Coal Geol 78:135-148

Li T (1994) Element abundances of China's continental crust and its sedimentary layer and upper continental crust. Geochemica 23(2):140-145 (in Chinese with English abstract)

Ren DY, Dai SF (2009) Potential coexisting and associated mineral resources in coal and coal-bearing Strata-an issue should pay close attention to. Coal Geology of China 21(10):1-4 (in Chinese with English abstract)

Ren DY, Zhao FH, Dai SF, Zhang JY, Luo KL (2006) Geochemistry of trace elements in coal. Science Press, Beijing, pp 1-551 (in Chinese with English abstract)

Seredin VV (1996) Rare earth element-bearing coals from the Russian Far East deposits. Int J Coal Geol 30:101-129

Seredin VV, Dai SF (2012) Coal deposits as potential alternative sources for lanthanides and yttrium. Int J Coal Geol 94:67-93

Taylor SR, McLennan SM (1985) The Continental Crust: Its Composition and Evolution. Oxford Press, Blackwell, p 312

Wang P, Pan ZL, Weng LB (1987) Systematic mineralogy (the 3rd volume). Geological Press, Beijing, pp 189-190 (in Chinese)

Wang ZG, Yu XY, Zhao ZH (1989) Geochemistry of rare earth elements. Science Press, Beijing, pp 1-535 (in Chinese)

Ward CR (2002) Analysis and significance of mineral matter in coal seams. Int J Coal Geol 50:135-168

Zhao ZG (2002) Research on rare earth elements geochemistry of coal-bearing strata. Coal industry Publishing House, Beijing, pp 1-115 (in Chinese)

Zheng LG, Liu GJ, Zhang HY, Gao LF, Xue J, Chou CL (2006) Study on geochemistry of rare earth elements (REEs) in Permian coal from Huaibei Coalfield. Geological Journal of China Universities 12(1):41-52 (in Chinese with English abstract)

Zhong MY, Yang BQ, Chen SH, Feng F, Zhu CS (2011) Sedimentay environment and accumulation regulations of Longtan Formation in Moxinpo, Chongqing. Journal of Henan University of technology 30(6):679-683 (in Chinese with English abstract)

Zou JH, Liu D, Tian HM, Liu F, Li T, Yang HY (2013) Geochemistry of trace and rare earth elements in the late paleozoic coal from Adaohai mine, Inner Mongolia. Journal of China Coal Society 38(6):1012-1018 (in Chinese with English abstract) 